\title{
Solar PV for Water Pumping and Irrigation
}

\section{PATAY ${ }^{1}{ }^{*}$, M. MONTVAJSZKI ${ }^{1}$}

\begin{abstract}
Water pumping for irrigation has a relatively high energy demand, depending on the applied irrigation method. At the same time, there is a considerable energy from the sun during the irrigation period. The solar PV (photovoltaic) technology may be suitable to ensure electric energy for pumping in many cases in agriculture, where the electric network is not available or reduction of the energy costs is wanted. There are some pilot plants for water pumping on the base of solar energy in the world and the spreading of these solar technologies is predictable. The solar energy based pumping process can be approached both in theoretical and experimental ways. In this paper, both the theoretical questions of the solar based pumping process and the experimental results of a model testing pump station powered by PV panels are shown.
\end{abstract}

Keywords: solar energy, irrigation, pumping, solar PV technologies

\section{Introduction}

Throughout the world, water supply and irrigation are the basic needs in agricultural production. The main aims of the water supplying in the arable lands and plantations are to

- ensure the elementary conditions of the production by water,

- increase the quantity of the yield,

- increase the quality of the yield,

- realize connected technological elements by irrigation (e.g. fertilizing, plant protection).

The quantity of water needed to irrigate a given land area depends on a number of factors, the most important being (Goswami ed., 1986):

- nature of the crop and the crop growth cycle,

- climatic conditions,

- type and condition of soil,

- land topography,

\footnotetext{
${ }^{*}$ Corresponding author. E-mail: patay.istvan@gek.szie.hu

1 Szent István University, Faculty of Engineering, Department of Process Engineering, Gödöllő, Páter K. út 1. 2100, Hungary
} 
- field application efficiency,

- water quality.

The added water demand usually changes from time to time, depending on the rain fall and the actual water demand of the crop.

Irrigation means an extra cost of the crop production. The cost of any irrigation has three elements: the cost of water, the energy and the human resource. The costs can be decreased by the water and energy saving irrigation methods and the automation of the applied system.

One possible way to reduce the energy cost is the utilization of local, renewable energy sources. The new and developing techniques in the field of solar and wind energy technologies give a good chance to establish sustainable irrigation plants, based on local energy sources.

During the vegetation period when irrigation is often needed, the radiation energy coming from the sun has a high value. This solar energy can be converted to electric energy by the photovoltaic (PV) applications for powering the irrigation pumps.

Some experimental studies are known from different sites of the world in the field of solar pumping. Most of them review the system installations and design (Abu-Aligah, 2011, Eker, 2005, Helikson et al., 1991, Waterman, 2012). The connection of solar PV pumping and irrigation is described only in a few papers, and usually the energetic analysis is not detailed in them. There is no information on solar PV pumping under the continental climate, for example in Europe. At the same time, many manufacturers offer solar PV pumping systems for the farmers without local experiences.

The main objectives of this study are:

- to analyse energy transformation process of water pumping,

- determination of the specific energy demand at different irrigation systems,

- evaluation of solar radiation conditions during the irrigation period in Hungary, and,

- testing a pump installation powered by solar energy and producing specific parameters for developing of solar PV pump stations.

\section{Materials and Methods}

1. Energy transformation process. Energetically, irrigation is an energy transforming process; energy transformation appears in the elements of the sys- 
tem during the irrigation period. The irrigation water needs defined energy for transportation and distribution, depending on the system and the specification of elements. The general scheme of this energetic system can be seen in Figure 1.

The input energy $\left(E_{i n}\right)$ is transformed to effective power energy $\left(E_{e}\right)$ by the power unit. The motoric losses of the power unit $\left(E_{m l}\right)$ depend on the type of the unit: the maximal efficiency is $40-45 \%$ for engines, and $80-85 \%$ for motors. But the actual efficiency is influenced strongly by the energetic adaptation of the power unit and the pump, and also determined by the operation conditions. The advantage of the engine driven pumps is the variable revolution of the engine. In this case, a relative high efficiency can be set. At the electric motor drive the same possibility can be realized only if the motor's speed is also variable. These installations are expensive but the extra investment returns in a long time operation.

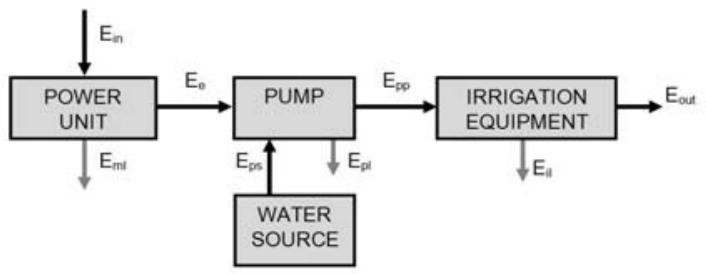

Fig. 1. The energetic process of irrigation

The general system shown in Figure 1 needs some supplementary elements at solar powered pumping system, as it is presented in Figure 2. The energy transformation process is more complicated because of the solar techniques (solar panel, inverter/charger, batteries and additional electric elements: cables, switches, etc.)

All of the parts of the solar PV drive irrigation system have certain energy losses; these are marked with grey arrows in Figure 2. The process can be analyzed based on the elements efficiency, if those are known.

1. Energy demand of irrigation. The power source demand is determined by the pumping conditions, namely the flow rate $(Q)$ and the total pressure required $\left(p_{t}\right)$. A solar PV power source can be used economically if the irrigation method is water and energy saving. For the developing of a solar PV energy source, the energy demand of the irrigation equipment is necessary. The specific energy demand of different irrigation systems can be calculated from the practical operation parameters given by the manufacturers.

2. Solar radiation conditions. A special meteorological station was developed for measuring the energetic parameters of the atmosphere in Szarvas, 


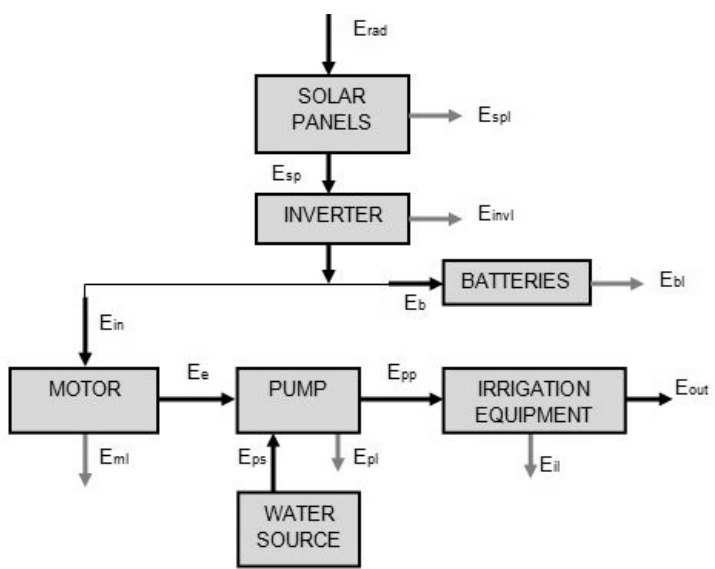

Fig. 2. Solar PV energetic processes for irrigation

2004. The VP 8605 type station's WEATHER RAD SENS application was able to collect very detailed radiation parameters for the estimation of solar energy. The sensor was programmed for 5 minutes test frequency, so the number of daily radiation data was 288 . The last ten years' results evaluation gives perfect basic parameters for developing solar PV systems to operate in the vegetation period, in the irrigation season.

3. Testing of model solar PV pump station. The system efficiency can be calculated for the solar PV pumps installation if the parameters of the elements are known. However, the real process may vary from the theoretical one. A model solar PV pump installation was built for testing the complete system as it is shown in Figures 3 and 4. The main elements of the pilot plants are:

- 2 piece of BP 585 PV solar panel, cascade, $2 \times 0,5 \mathrm{~m}^{2}$

- 2 piece of $12 \mathrm{~V} 154$ Ah batteries, cascade

- 1 piece of SU 1400 INET APC inverter (AC/DC),

- 1 piece of VB-0,25-20 single phase motor driven centrifugal pump,

- instrumentation:

- AS 1 radiation sensor,

- P15 pressure sensor,

- C717.01 induction volume meter,

- digital consumption meters,

- ADVANTECH PCL 1711 PC card

- current and voltage meters.

The tests were carried out at the Szent István University, Faculty of Szarvas, Department of Technical and Environmental Techniques, in June and July of 2011. 


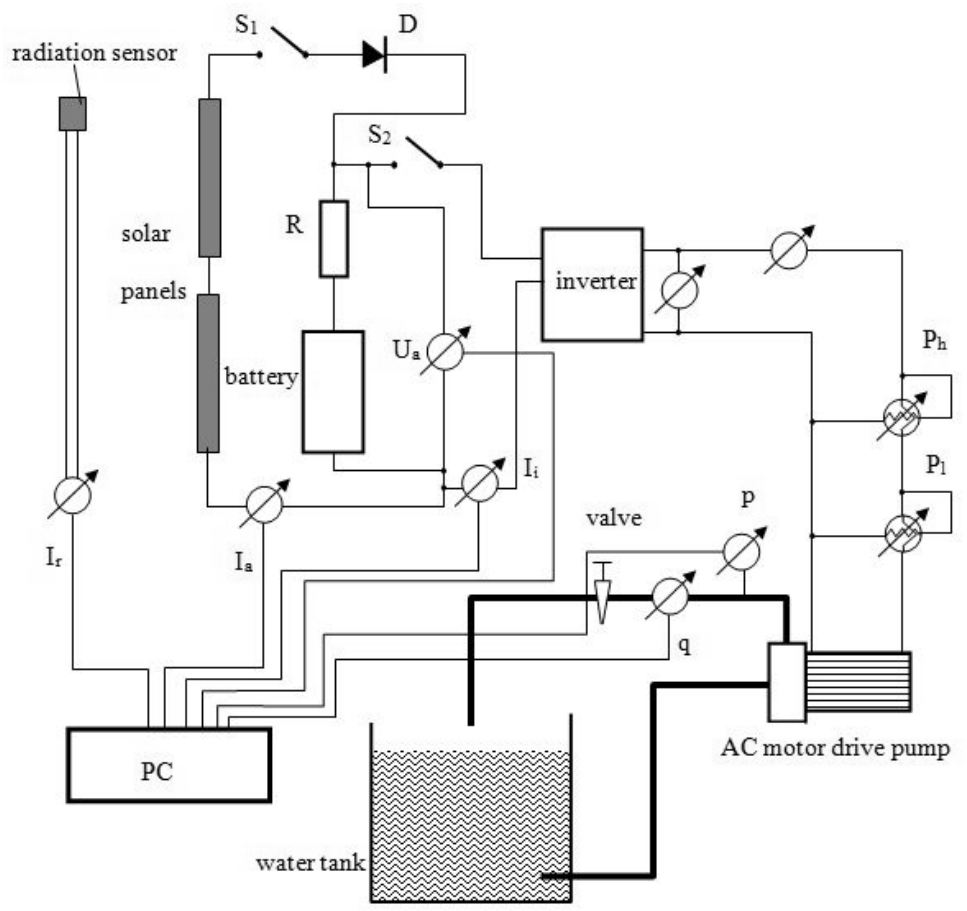

Fig. 3. The pilot solar PV pump station and instrumentation Notes: $\mathrm{S}_{1}, \mathrm{~S}_{2}$ : switches, R: resistance, D: diode, PC: test computer, $\mathrm{P}_{\mathrm{h}}$ and $P_{1}$ : electric power meters

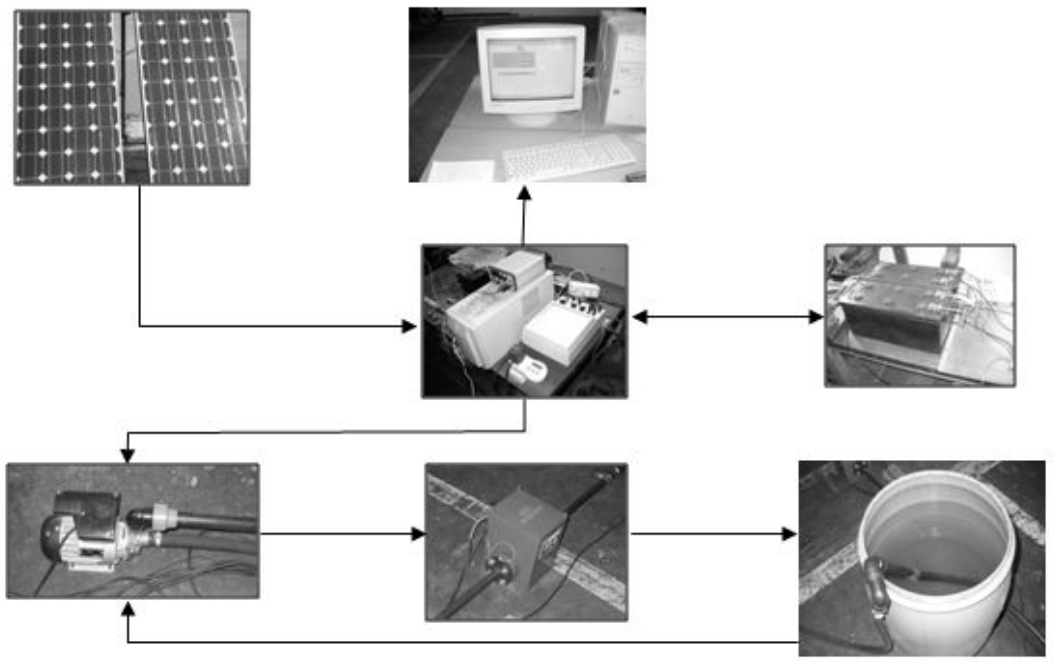

Fig. 4. Main elements of the pilot plant 


\section{Elements of the Solar PV Irrigation Systems}

Solar panels. The intensity of electric energy production of the PV cells or panels depends on the intensity of solar radiation. The quality of energy transformation or the efficiency of the process is determined by the type of cells. Four types of cells are in general applications, depending on the manufacturing process for pumping process

- monocrystalline cells,

- polycrystalline cells,

- amorphous silicon cells,

- hybrid PV cells.

Table 1. Main characteristic of PV cells (EvoEnergy, 2012)

\begin{tabular}{|c|c|c|c|}
\hline Type of cell & Surface & $\begin{array}{c}\text { Efficiency } \\
{[\%]}\end{array}$ & Relative price \\
\hline Mono crystalline & & $13-17$ & 1 \\
\hline Poly-crystalline & & $11-15$ & 0.6 \\
\hline Amorphous & & $6-8$ & $0.2-0.7$ \\
\hline Hybrid PV & & $>18$ & $1.5-3$ \\
\hline
\end{tabular}

For solar PV pumping, mono- and polycrystalline panels are usually recommended, because of the favourable price/efficiency relation (Table 1). The mono crystalline PV cells have efficiencies of $13-17 \%$ and are the most efficient type of the three basic types of silicon PV cell. Mass-produced polycrystalline PV cell modules have an efficiency of $11-15 \%$. Amorphous 
silicon PV cells made from non-crystalline semiconductor material with a thin film technology. These PV cells have an efficiency of between 6-8\%. Hybrid photovoltaic cells are classified as PV cells, including two different types of PV technologies. The Hybrid PV cell shown here is made by Sanyo and comprises a monocrystalline PV cell covered by an ultra-thin amorphous silicon PV layer. The advantages of these types of cells are that they perform well at high temperatures and maintain higher efficiencies (over 18\%) than conventional silicon PV cells. However, these cells are the most expensive.

Inverters. Inverter is an electronic device or circuit that changes direct current (DC) to alternating current (AC). A solar power inverter can be entirely electronic or may be a combination of mechanical effects (such as a rotary apparatus) and electronic circuitry. Static inverters do not use moving parts in the conversion process.

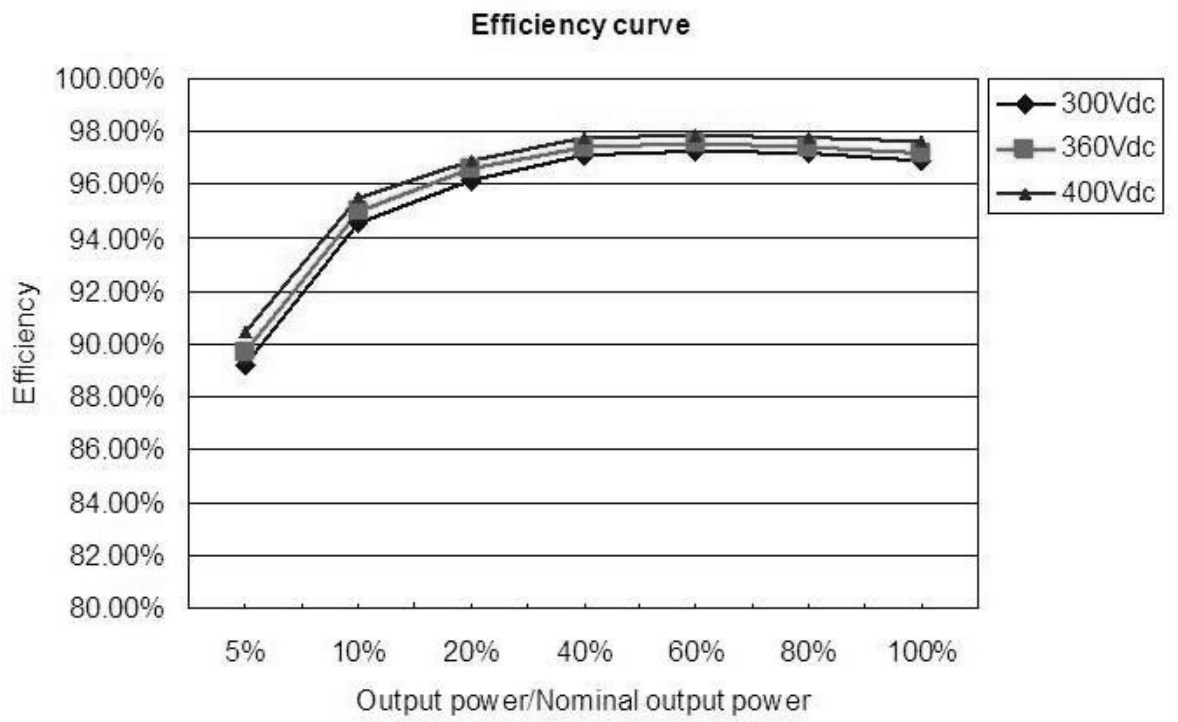

Fig. 5. The typical load-efficiency function of inverter (http://jfy-tech.en.alibaba.com/product)

Advanced solar pumping inverters convert DC voltage into AC voltage to drive pumps directly, without the need for batteries or other energy storage devices. By utilizing MPPT (maximum power point tracking), solar pumping inverters regulate output frequency to control the speed of the pumps, in order to save the pump motor from damage. Solar pumping inverters usually 
have multiple ports: an input of DC current generated by PV arrays, one port is an output of AC voltage, and a further one for input of a water-level sensor.

The efficiency of any inverters depends on the load. The efficiency has a maximum at the maximum load (at the nominal power capacity) and if the load reduces, the efficiency also reduces. The general function of loadefficiency is shown in Figure 5. Hence the efficiency of the inverter changes in wide scale at the direct solar PV drive pumps, applying battery compensated powering the efficiency can be kept at a high level. The maximal value of the inverters efficiency can reach 95-97\%, at an energetically well-settled system.

Solar batteries. There are many types of batteries made for solar PV application. A deep cycle battery bank can provide a relatively constant source of power when the grid is down, or during periods when the photovoltaic system is not producing power. The efficiency of energy storage in batteries depends on both the charge and load process. Two efficiency parameters are in use in the practice: the charge efficiency (amp-hours-efficiency) and the power efficiency (watt-hours-efficiency). The total storage efficiency can be calculated as a result of multiplying of these two process efficiencies.

Tests results show that the efficiency strongly depends on the status-ofcharge, SOC. These tests indicate that from zero SOC to $84 \%$ SOC the average overall battery charging efficiency is $91 \%$, and that the incremental battery charging efficiency from $79 \%$ to $84 \%$ is only $55 \%$ (Stevens and Corey, 2012). Figure 6 shows the conversion of the amp-hours out versus amphours into efficiencies. Note that there are two curves; one is displaying overall efficiency from zero state of charge to the particular state

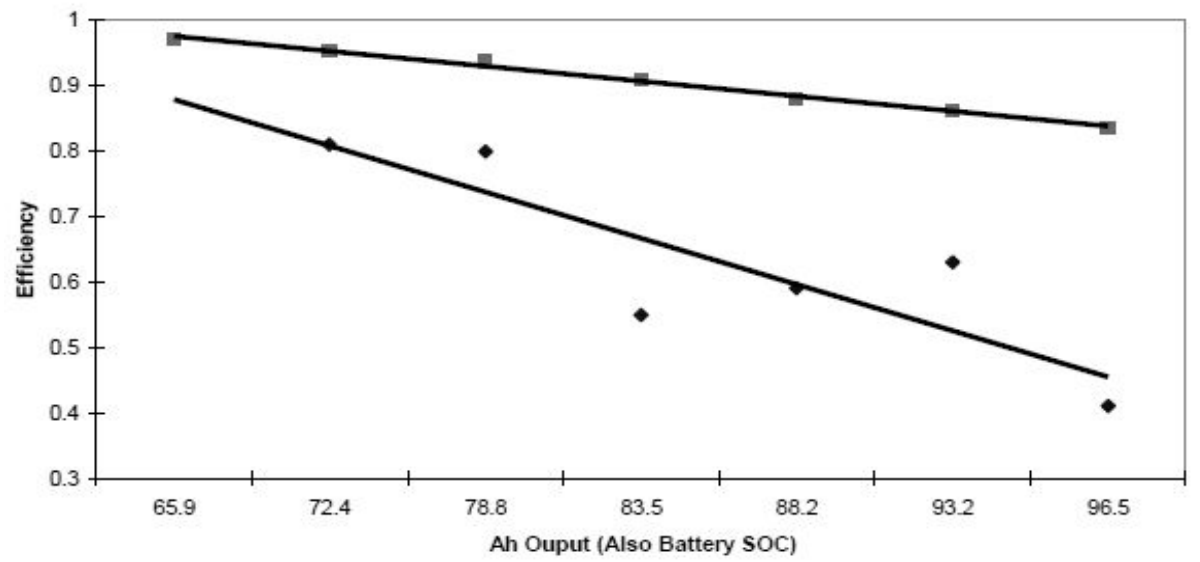

Fig. 6. Battery efficiency curves (Stevens and Corey, 2012) 
of charge under test, and the other showing incremental efficiency between states SOC. The overall efficiency shows high values, with full charge represented by approximately $85 \%$ efficiency, a commonly used value for battery charge efficiency. More importantly, notice the dramatically lower efficiencies for the increments above about $80 \%$ state of charge, where most values are below $60 \%$ efficiency, and full charge is represented by less than $50 \%$ efficiency.

Usually about $80 \%$ of total storage efficiency is expected at the solar PV applications. This efficiency level can be reached at above 90\% charge and $85 \%$ loading efficiency values.

Solar pumps. There are a number of types of electric water pumps for different operational conditions. These are (Goswami ed., 1986, Stetson and Mecham ed., 2012)

- Jack pump: experience has shown that the currents to the motor vary by a factor of five during the operation. Unless batteries are used on the systems, this promotes extremely inefficient use of the PV energy source.

- Jet pump: the efficiency of this system is between 5 and $10 \%$ and is not suitable for use with photovoltaic.

- Centrifugal pump with DC motor on surface: the main advantage of this pump is that the surface-mounted DC motor is easily accessible for periodic replacement of brushes.

- Submersible centrifugal pump with AC motor: a major problem with $\mathrm{AC}$ motors is the high starting current required. If the $\mathrm{AC}$ motor connected to a pump is started, the starting current is of the order of five to eight times of running current. It needs a suitable high capacity of batteries at a solar PV system.

- Centrifugal pump with brushless DC motor: there is an electronic controller instead of brushes at this motor. The main advantages of this system are the high efficiency (over 90\%), long life expectancy and low maintenance costs. Some types of these pumps can be operated in AC mode directly too, without any reinstallation.

Nowadays, solar pumps fall into two major categories

- surface pump, which includes pressure, delivery, and booster pumps and

- submersible pump - primarily submersible well pumps. 
The total efficiency of the solar motor-pump units can be expected for 70$80 \%$, depending on the energetic setting of the pump and the irrigation equipment.

\section{Results and Discussion}

Estimation of system efficiency. The solar PV pump station's efficiency shows the quality of the total energy transformation. One of the main objectives is to ensure the highest possible efficiency during the design process. The system efficiency can be estimated in advance, based on the part element's projected efficiency data given by the manufacturers and taking account of the experimental data.

The main data for the expected system efficiency calculation is collected in Table 2. The results show that $2-10 \%$ of system efficiency can be expected at a solar PV pump station, depending on the quality of the elements and the energetic accommodation.

Table 2. System efficiency of solar PV pump station

\begin{tabular}{|l|c|c|}
\hline \multicolumn{1}{|c|}{ Part units } & Efficiency minimum & Efficiency maximum \\
\hline Solar panel & 0.06 & 0.17 \\
\hline Inverter & 0.9 & 0.95 \\
\hline Batteries & 0.6 & 0.8 \\
\hline Pump unit & 0.7 & 0.8 \\
\hline System & $\mathbf{0 . 0 2 2 7}$ & $\mathbf{0 . 1 0 3}$ \\
\hline
\end{tabular}

\subsection{Energy demand of irrigation}

General notices. The demand of the transition and outlet pressure (namely the hydraulic power demand) is determined by the irrigation system and the construction of the actual equipment. But general rule is that the energy demand is influenced by the outlet pressure, if the distributed flow rate is constant. The energy demand of any irrigation equipment is:

$$
E=10^{2} \cdot Q_{t} \cdot p_{t} \cdot t_{i} \quad[\mathrm{~kJ}]
$$

where $Q$ : the distributed flow rate, $\left[\mathrm{m}^{3} \cdot \mathrm{h}^{-1}\right]$

$p_{t}$ : the total pressure (pressure demand of the suction + transition + outlet), [bar]

$t_{i}$ : the operation time of the irrigation, [h] 
The irrigation time $\left(t_{i}\right)$ can be calculated from the intensity of the irrigation (i) and the dose of the irrigated water, $h$ :

$$
t_{i}=\frac{h}{i} \quad[\mathrm{~h}]
$$

(Dimensions of (2) is: $h$ in [mm], $i$ in [mm.h-1].)

The effective average intensity of the irrigation can be calculated as:

$$
i=10^{3} \cdot \frac{Q}{A} \quad\left[\mathrm{~mm} \cdot \mathrm{h}^{-1}\right]
$$

where $A$ is the area irrigated together at same time, $\left[\mathrm{m}^{2}\right]$.

The energy demand of the irrigation based on (2) and (3):

$$
E=10^{2} \cdot A \cdot i \cdot p_{t} \cdot \frac{h}{i}=10^{2} \cdot A \cdot p_{t} \cdot h \quad[\mathrm{~J}]
$$

The base of the evaluation or comparison of the different irrigation methods or equipments may be a kind of specific parameter. While in (4) there are three variable parameters and three specific values can be composed.

- The specific energy of water dose unit is:

$$
E_{h}=\frac{E}{h}=10^{2} \cdot A \cdot p_{t} \quad\left[\mathrm{~J} \cdot \mathrm{mm}^{-1}\right]
$$

- The specific energy of the irrigated area unit:

$$
E_{A}=\frac{E}{A}=10^{2} \cdot p_{t} \cdot h \quad\left[\mathrm{~J} \cdot \mathrm{m}^{-2}\right]
$$

- The specific energy demand of the flow rate unit of the irrigated water:

$$
E_{Q}=\frac{E}{Q}=10^{2} \cdot \frac{h}{i} \cdot p_{t}=10^{2} \cdot p_{t} \cdot t_{i} \quad\left[\mathrm{~kJ} \cdot\left(\mathrm{m}^{3} \cdot \mathrm{h}^{-1}\right)^{-1}\right]
$$

For the comparison of different irrigation techniques in energetic aspect equation (7) may be suggested. But during the evaluation process there are problems with the explanation of the intensity. Equation (7) shows the inverse proportion of the energy demand and the intensity (Figure 7). Because of different water distribution methods, the intensity of the irrigation is specific for the irrigation system and the actual equipment.

Sprinkler irrigation. At the sprinkler irrigation the average intensity of the water and the total pressure changes in a relatively wide range depending on the construction of the equipment. Generally the higher intensity needs larger pressure. 


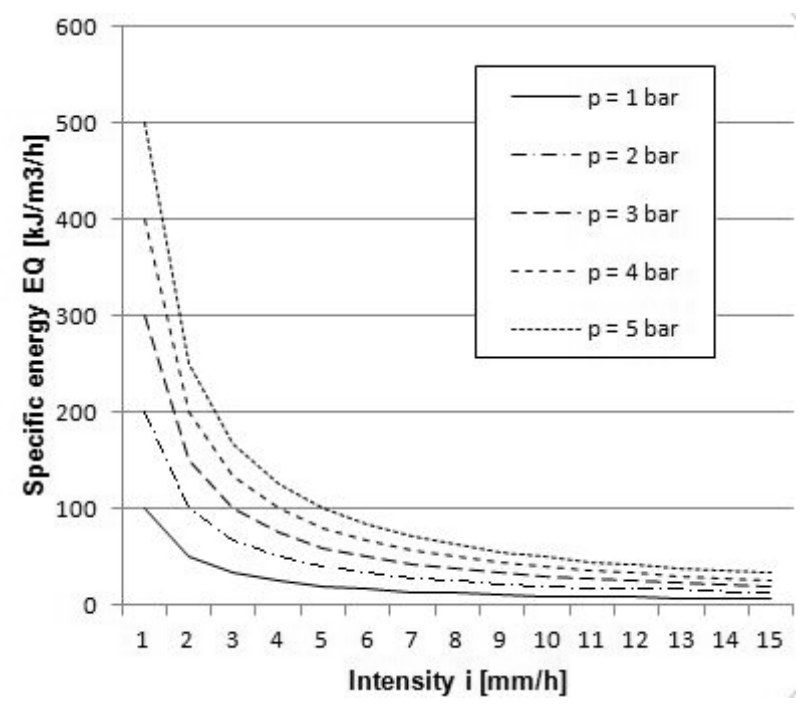

Fig. 7. Specific energy demand $\left(E_{Q}\right)$ as function of intensity $(i)$

In order to compare the different sprinkler irrigation techniques in the aspect of energy demand a new specific parameter is needed. Based on (7) the next equation can be written:

$$
E_{Q h}=\frac{E_{Q}}{h}=10^{2} \cdot \frac{p_{t}}{i} \quad\left[\mathrm{~kJ} /\left(\mathrm{m}^{3} \cdot \mathrm{h}^{-1}\right) \mathrm{mm}\right]
$$

$E_{Q h}$ means the specific energy demand to correlate the flow rate unit and the dose unit of the water. The equation (8) is used to calculate the $E_{Q h}$ values of the practical interval of total pressure and intensity. The results can be seen in the Table 3 .

Table 3. Specific energy demand of the sprinkler irrigation (Patay et al., 2012)

\begin{tabular}{|l|c|c|c|}
\hline \multicolumn{1}{|c|}{$\begin{array}{c}\text { Irrigation equip- } \\
\text { ment }\end{array}$} & $\begin{array}{c}\text { Pressure } \\
p_{t} \\
{[\mathrm{bar}]}\end{array}$ & $\begin{array}{c}\text { Average intensity } \\
i \\
{\left[\mathrm{~mm} \cdot \mathrm{h}^{-1}\right]}\end{array}$ & $\begin{array}{c}\text { Specific energy de- } \\
\text { mand } \\
E_{Q h} \\
{\left[\mathrm{~kJ} /\left(\mathrm{m}^{3} \cdot \mathrm{h}^{-1}\right) \mathrm{mm}\right]}\end{array}$ \\
\hline Micro sprinklers & $2-4$ & $1-5$ & $40-200$ \\
\hline Moving systems & $3-4$ & $5-10$ & $60-80$ \\
\hline $\begin{array}{l}\text { Reel system with } \\
\text { console }\end{array}$ & $4-5$ & $5-10$ & $40-50$ \\
\hline $\begin{array}{l}\text { Reel system with } \\
\text { single sprinkler }\end{array}$ & $5-10$ & $10-20$ & $20-100$ \\
\hline
\end{tabular}


As it can be observed in Table 3, there are no significant differences among the specific energy demands of different sprinkler irrigation systems, except the micro sprinkler irrigation, where the specific energy value can reach the highest value of $200 \mathrm{~kJ} \cdot\left(\mathrm{m}^{3} \cdot \mathrm{h}^{-1}\right)^{-1} \mathrm{~mm}^{-1}$. So in the energetic aspect, the micro sprinkler irrigation is relatively expensive for rainfall irrigation. But water losses and so the energy losses - at the sprinkler irrigation replacement - should be taken into account. The reason of water losses can be the evaporation in the atmosphere, the transition effect of the wind and the evaporation of the soil surface. At unfavourable conditions, the waterand energy losses can reach the $30-50 \%$ value, too.

Drip irrigation. The drip or trickle irrigation usually is applied mainly in plantations, in arable land horticulture and greenhouses. Common characteristic of the drip systems is the spot water distribution, along the pipelines. If the pipeline is made of porous material, the water can be percolated on the wall of the pipeline; the wetted area is linear in this case. At the drip irrigation systems, intensity is not an evident parameter.

The definition of the intensity at drip irrigation systems is really correct if the irrigated water volume is referred the total irrigated area:

$$
i=\frac{q_{A}}{A_{b}}=\frac{n \cdot q_{1}}{a \cdot b} \quad\left[\mathrm{~mm} \cdot \mathrm{h}^{-1}\right]
$$

where $q_{A}$ : the irrigated flow rate of the breeding area, $\left[\mathrm{dm}^{3} \cdot \mathrm{h}^{-1}\right]$

$q_{1}$ : flow rate of the single dripper element, $\left[\mathrm{dm}^{3} \cdot \mathrm{h}^{-1}\right]$

$n$ : number of drippers per breeding area,

$A_{b}$ : breeding area per plant, $\left[\mathrm{m}^{2}\right]$

$a$ and $b$ : the distance of the rows and plants, $[\mathrm{m}]$

If one dripper pipeline is installed for irrigating of a row, the number of drippers per breeding area is $n=b / t$, where $t$ is the distance of the dripper elements along the pipeline in [m]. The intensity in this case is:

$$
i=\frac{q_{1}}{t \cdot a} \quad\left[\mathrm{~mm} \cdot \mathrm{h}^{-1}\right]
$$

The specific energy demand of drip irrigation system is given by (9) and (10):

$$
E_{Q h}=10^{2} \cdot \frac{p_{t} \cdot t \cdot a}{q_{1}} \quad\left[\mathrm{~kJ} /\left(\mathrm{m}^{3} \cdot \mathrm{h}^{-1}\right) \mathrm{mm}\right]
$$

Equation (11) shows clearly how the specific energy demand is influenced by the operational parameters. Table 4 shows the data calculated by the equation for some typical operation conditions. 
From the data of Table 4 it can be seen clearly that the specific demand of energy changes in wider interval at the drip irrigation than at the sprinklers as shown in Table 4. The conclusion is that the drip irrigation may be energy saver or energy intensive depending on the operational characteristics, namely on the scheme of the pipelines (a), on the specific number of the drippers along the pipeline $(t)$, the pressure and the volume rate of the drippers.

The specific energy demand data for the sprinkler and drip irrigation are important for determining pump capacity and power demand.

Table 4. The specific energy demand of trickle irrigation (Patay et al, 2012)

\begin{tabular}{|c|c|c|c|c|}
\hline $\begin{array}{c}\text { Pressure } \\
\qquad p_{t} \\
{[\text { bar }]}\end{array}$ & $\begin{array}{c}\text { Distance of } \\
\text { elements } \\
t \\
{[\mathrm{~m}]}\end{array}$ & $\begin{array}{c}\text { Distance of } \\
\text { rows } \\
a \\
{[\mathrm{~m}]}\end{array}$ & $\begin{array}{c}\text { Flow rate of } \\
\text { drippers } \\
q_{1} \\
{\left[\mathrm{dm}^{3} / \mathrm{h}\right]}\end{array}$ & $\begin{array}{c}\text { Specific energy } \\
E_{Q h} \\
{\left[\mathrm{~kJ} /\left(\mathrm{m}^{3} \cdot \mathrm{h}^{-1}\right) \mathrm{mm}\right]}\end{array}$ \\
\hline 1 & $\begin{array}{l}0.2 \\
0.4 \\
0.6 \\
0.8\end{array}$ & $\begin{array}{l}0.5 \\
1.0 \\
1.5 \\
3.0\end{array}$ & $\begin{array}{l}1.5 \\
2.0 \\
2.5 \\
3.0\end{array}$ & $\begin{array}{c}7 \\
20 \\
36 \\
60\end{array}$ \\
\hline 2 & $\begin{array}{l}0.2 \\
0.4 \\
0.6 \\
0.8\end{array}$ & $\begin{array}{l}0.5 \\
1.0 \\
1.5 \\
3.0\end{array}$ & $\begin{array}{l}1.5 \\
2.0 \\
2.5 \\
3.0\end{array}$ & $\begin{array}{c}13 \\
40 \\
72 \\
160\end{array}$ \\
\hline 3 & $\begin{array}{l}0.2 \\
0.4 \\
0.6 \\
0.8\end{array}$ & $\begin{array}{l}0.5 \\
1.0 \\
1.5 \\
3.0\end{array}$ & $\begin{array}{l}1.5 \\
2.0 \\
2.5 \\
3.0\end{array}$ & $\begin{array}{c}20 \\
60 \\
108 \\
240\end{array}$ \\
\hline
\end{tabular}

\subsection{Solar radiation conditions}

The irrigation period practically coincides with the vegetation time for most of the plants produced on arable land. That is why solar radiation data is important from May to September. Figure 8 shows the sum of daily radiation data observed during the whole irrigation period of 2011. Note that there are large differences between the daily data; the values change between 3 and $33 \mathrm{MJ} / \mathrm{m}^{2}$ values. Also the periodicity of the radiation sums is noteworthy. This is a consequence of fronts coming about 10 days in summer time with a covered sky condition. The total sum of the solar radiation is $3.394 \mathrm{MJ} / \mathrm{m}^{2}$, or $943 \mathrm{kWh} / \mathrm{m}^{2}$. The average value is $21 \mathrm{MJ} / \mathrm{m}^{2} \cdot$ day $(5.8$ $\mathrm{kWh} / \mathrm{m}^{2} \cdot$ day) for the irrigation period. These specific data of solar radiation can be the basis of the design calculations. 


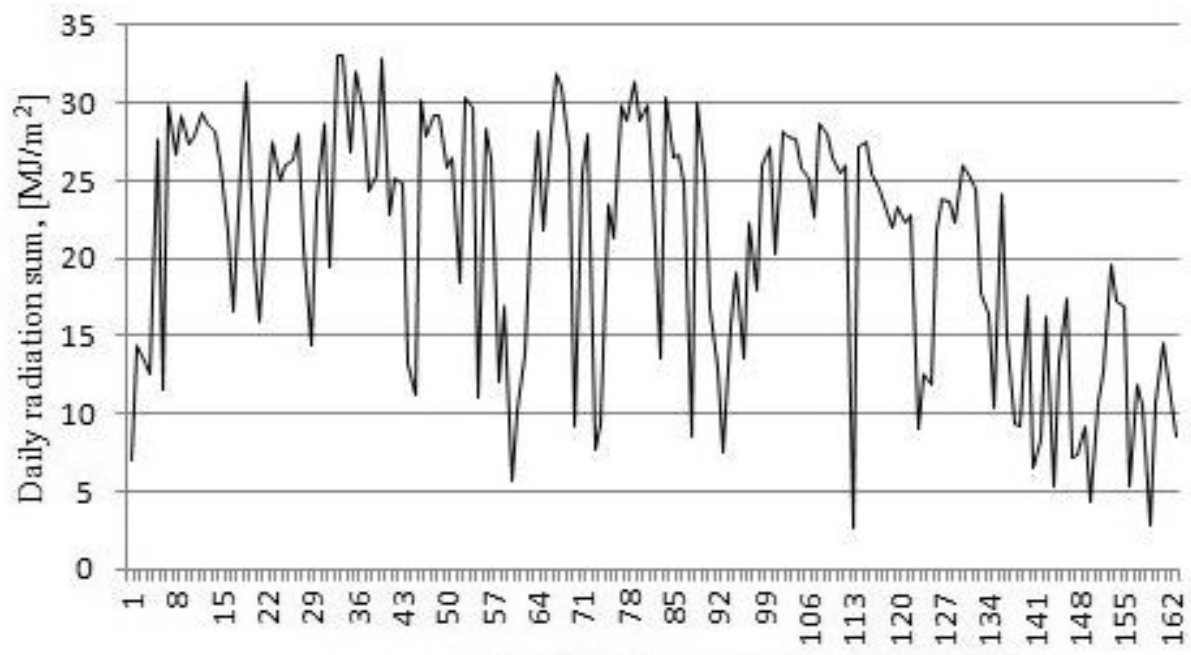

Number of days, 28.04. - 30.09. 2011.

Fig. 8. The daily radiation sum during the irrigation period in 2011

(Data from the database of SZIU Tessedik Campus, Szarvas)

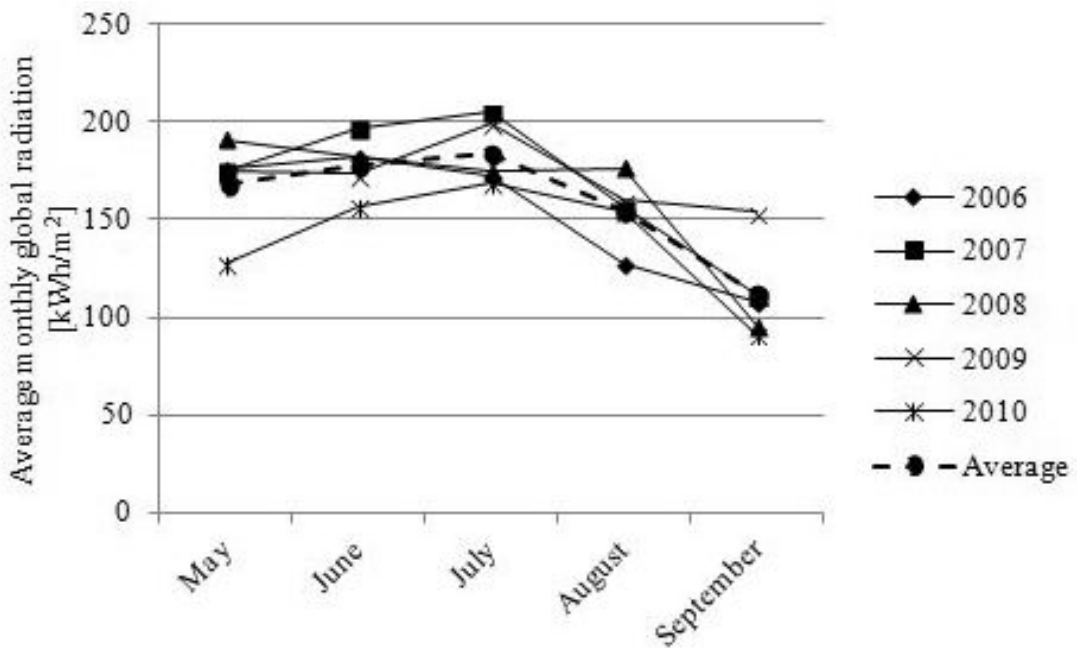

Fig. 9. Monthly global radiation in the irrigation periods

Figure 9 shows the monthly global radiation data for a 5-year period. There is also a considerable difference between the yearly sunlight perspectives. The variation is about $\pm 25 \mathrm{kWh} / \mathrm{m}^{2}$ month, namely $\pm 20 \%$ difference from the average value. The year 2010 was excluded from the data, when the solar radiation was extremely low. This year was particularly cold and 
rainy in summer with a low evapotranspiration. Irrigation is not necessary in these years in arable lands.

The solar radiation energy data for the tested years seems to be a balanced amount of energy (Figure 10). As the diagram indicates the total energy value is about $800 \mathrm{kWh} / \mathrm{m}^{2}$ year, except the mentioned 2010 . Based on the data, this value is suggested as a basis input energy for developing solar power PV pump stations in the region of the Great Plain, where most of the irrigated arable lands can be found. But of course the solar PV powered irrigation is successfully applicable not only on arable lands but also in green houses.

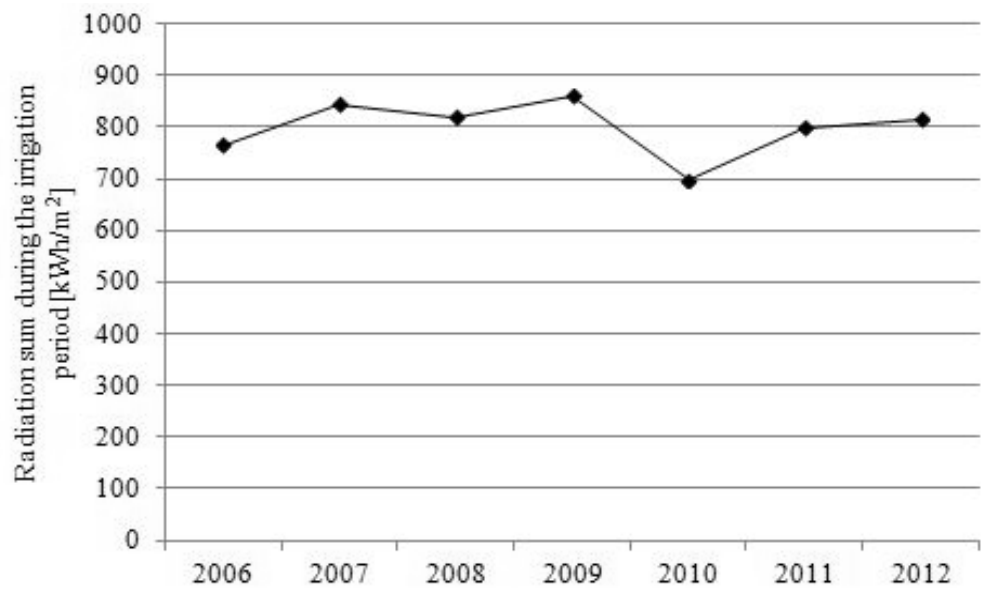

Fig. 10. Solar radiation energy sum during the irrigation period

\subsection{Results of model solar PV pumping}

The pilot plant was introduced earlier and realizes an energy transformation process as shown in Figure 11, where the $I_{r}$ is the solar radiation power, $P_{s p}$ is the electric power of the solar panels, $P_{b}$ is the additional power of the battery, $P_{i}$ is the inverter inlet power, $P_{p}$ is the pump power or the inverter outlet power and $P_{h}$ is the hydraulic power of the pump.

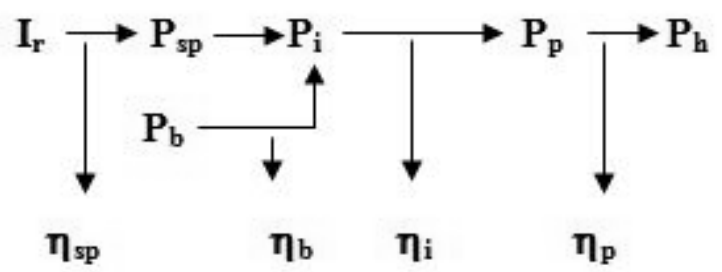

Fig. 11. Energy transformation process of the pilot plant 
The system efficiency is given by the equation:

$$
\eta_{s}=\frac{P_{h}}{A \cdot I_{r}+P_{b}}=\eta_{s p} \cdot \eta_{b} \cdot \eta_{i} \cdot \eta_{p}
$$

where $A$ is the effective surface of solar panels, $\eta_{s p}$ is the efficiency of solar panels, $\eta_{b}$ is the efficiency of batteries, $\eta_{i}$ is the efficiency of inverter and $\eta_{p}$ is the efficiency of the pumping. Equation (12) shows that the system efficiency depends on the hydraulic power and the input power ensured by the solar panel power and the power of battery. But the instrumentation system provides an opportunity to analyze some sub-processes, too.

Solar PV panel tests. The most important energy parameters of the solar PV panels are the nominal voltage, the current, the effective power and the efficiency. All of these characteristics can be given as a function of solar radiation. A typical characteristic of the solar cells is that voltage is practically constant and is independent of the solar radiation intensity. At the same time, the actual current depends on radiation; the connection is linear between them. Therefore, the effective power of the panels is also a linear function of the solar radiation, while the efficiency is constant. These functions can be seen on Figure 12 for the tested solar PV panels. The obtained 10\% efficiency value can be achieved by a monocrystalline type solar panel.
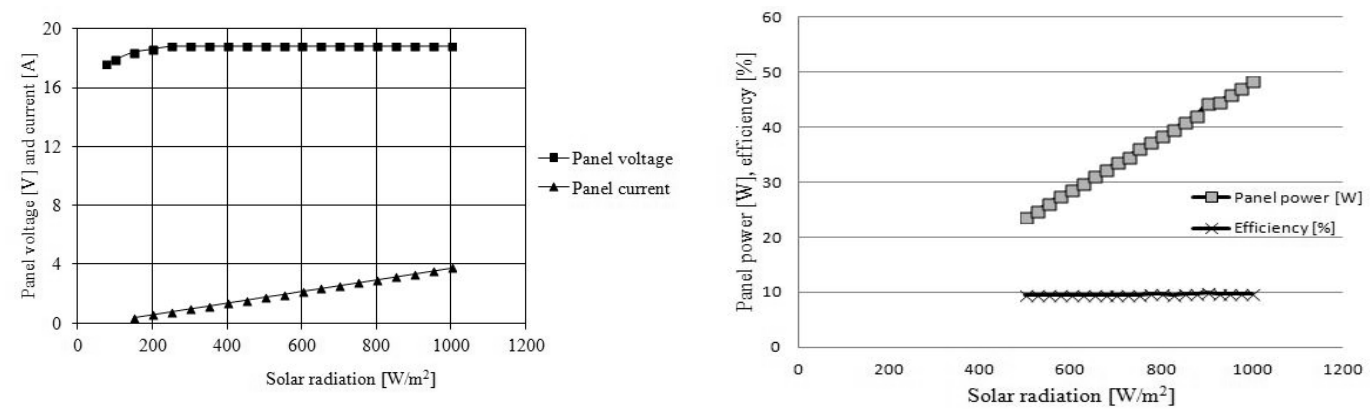

Fig. 12. The operation curves of the tested solar PV panels

The maximum current from the two cascade panels is limited to 6-8 A, depending on radiation intensity.

Pumping tests. The pumping tests were static in the sense that the hydraulic power was kept at a constant value. It means that the flow rate and the pressure were constant during the test. This pump operation corresponds to an irrigation process or a water tank filling for irrigation. The measurements were conducted throughout the day. The following test results were conducted on $1^{\text {st }}$ of July, 2011. On this day, the sky was clear a.m. and variably 
cloudy afternoon, as it is shown in Figure 13a. Since the load was constant, the panel current followed the radiation intensity (Figure 13b).

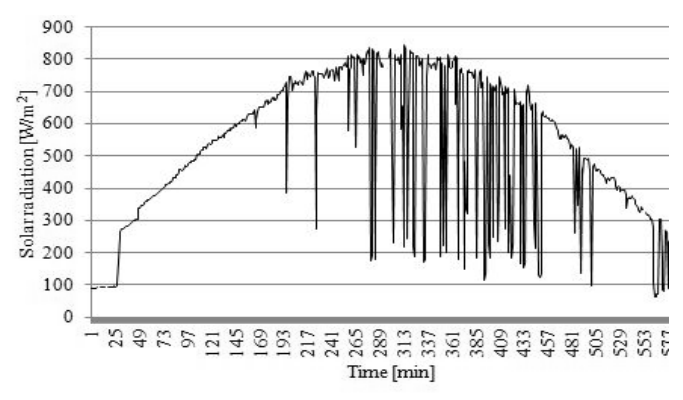

(a)

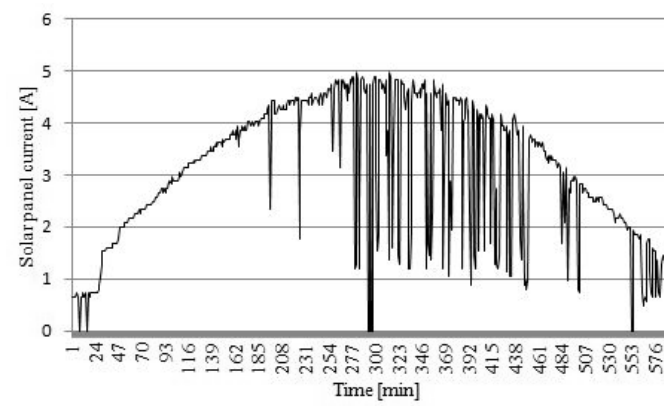

(b)

Fig. 13. The solar radiation (a) and the panel current (b) during the test

The average solar panel current was 3,4 A, the intverter input current was $15 \mathrm{~A}$. The difference between the inverter input current and the panel current was covered by the batteries. So the input electric pumping energy ratio for the whole test period was $23-77 \%$. It means $360 \mathrm{~W}$ electric power in the DC circuit, about $83 \mathrm{~W}$ from the solar panel, in average.

The hydraulic power can be calculated from the flow rate and the pressure. Since the flow rate was $0,46 \mathrm{dm}^{3} / \mathrm{s}$ and the pressure was $75 \mathrm{kPa}(0.75$ bar, $7.5 \mathrm{~m}$ head), the hydraulic power was $34.5 \mathrm{~W}$ during the test. The main results based on these data are:

- the panel efficiency during the tests was $10 \%$, according to the expected value of a monocrystalline type solar PV panel

- the efficiency of the inverter and the motor-pump unit together is also about $10 \%$, less than it was expected. The main reason for this is that both the inverter and the motor were energetically underloaded and this operation associated with low efficiency

- overall, the total system's efficiency is near $1 \%$, as it was calculated from the data, without the battery efficiency, which was not tested.

As it was mentioned, the low loaded elements of the AC circuit caused low efficiency. This draws attention to the importance of the energy correspondence of the system elements. Higher efficiency value can be achieved when all elements of the system operate near their power limit. 


\section{Conclusions}

Some irrigation techniques need a relative low specific energy demand. These are mainly the micro irrigation systems, especially the low pressure (1-1.5 bar) drip irrigation equipments and micro sprinklers. Besides the low energy demand, the water flow rate is moderate at these systems. Since the solar radiation has maximum in the irrigation period, the solar PV techniques may be suitable for water supplement and irrigation in the agriculture economically. The tests show that the average solar radiation is nearly $800 \mathrm{kWh} / \mathrm{m}^{2}$ during May-September period on the Great Hungarian Plain. This solar energy volume can be used to operate solar PV based pump stations. Because solar radiation energy - hydraulic energy transformation process is complicated, exact information is needed for developing a solar PV based irrigation.

Any energy transformation process can be characterized by the system's efficiency. The theoretical and experimental test results show that the system efficiency is relatively low at the solar PV systems. The main reason is the low efficiency of the solar cells and panels. Depending on the type of solar cell technology, the efficiency of the solar radiation energy - electric energy transformation is about $10 \%$ or lower. The other transformation processes (DC AC conversion, electric energy - mechanical energy - hydraulic energy) generate further losses in the system. The solar PV pumping tests show that the expected system efficiency is about maximum $1-2 \%$, depending on the construction of the system and the quality of the elements (solar PV panels, inverter, and motor-pump unit). Important experience of the tests is that the energy load of these elements measurably influences the system's efficiency: an underloaded inverter and electric pump reduce the efficiency value.

The data of tests and the results introduced in this paper may help develop solar PV pumping and irrigation in the spirit of "good practice".

\section{References}

Abu-Aligah, M. (2011): Design of photovoltaic water pumping system and compare it with diesel powered pump, Jordan Journal of Mechanical and Industrial Engineering, Vol. 5, Number 3, 173-180

Eker, B. (2005): Solar powered water pumping systems, Trakia Journal of Sciences, Vol. 3, No. $7,7-11$

EvoEnergy Ltd. Internet site: http:/ / www.evoenergy.co.uk/solar-pv/, 08.01.2014.

Goswami, D.Y. (ed) (1986): Alternative energy in agriculture. Vol.II. CRC Press Inc., Boca Raton, Florida, USA 
Helikson, H.J., Haman, D.Z. \& Baird, C.D. (1991): Pumping water for irrigation using solar energy, Univ. of Florida, Fact Sheet EES-63.

Johanson, T.B., Kelly, H., Reddy, A.K.N. \& Williams, R.H. (eds) (1993): Renewable energy. Sources for fuels and electricity. Island Press, Washington DC. USA

McDuff, E. (ed), (2010): Design of small photovoltaic (PV) solar-powered water pump systems. USDA, Technical Note, No. 28. Portland, Oregon

Patay, I., Montvajszki, M. \& Gergely, Z. (2012.): Energy demand of irrigation. Energy and carbon saving in the practice, Hungarian Agricultural Engineering, Vol. 24, 2629

Stetson, V.E. \& Mecham,B.Q. (eds), (2012.): Irrigation. Sixth edition. Irrigation Association, Falls Church, VA, USA

Stevens, J. W. \& Corey, G. P. (2012): Lead_Acid_Battery_Efficiency, http://www.otherpower.com/images/scimages/7427/, 15.01.2015.

Yiasoumi, B.: Selecting an irrigation pump. Agfact E5.8. Third edition. Internet site: http://www.dpi.nsw.gov.au/agriculture/resources/water/irrigation/systems/pu mps/selecting, 10.01.2014.

Waterman, B. (2012): Solar Water Pumping Basics, http://newfarmerproject.wordpress.com/2012/06/14/solar- water- pumping- basics/, 15.01.2015.

http://jfy-tech.en.alibaba.com/product, 21.09.2015. 